\title{
Rejected, Isolated, and Abused Social Stigma toward The Sinners in Aceh
}

\author{
Deni Yanuar \\ Department of Communication \\ Faculty of Social and Political Sciences \\ Syiah Kuala University \\ Banda Aceh, Indonesia \\ deniyanuar@unsyiah.ac.id
}

\author{
Hamdani M. Syam \\ Department of Communication \\ Faculty of Social and Political Sciences \\ Syiah Kuala University \\ Banda Aceh, Indonesia \\ Febri Nurrahmi \\ Department of Communication \\ Faculty of Social and Political Sciences \\ Syiah Kuala University \\ Banda Aceh, Indonesia
}

\begin{abstract}
Canning is the most stringent punishment imposed on those who violate the Sharia law in Aceh, not in terms of the physical pain suffered but the inherent distress of social stigma repressed by the community. The impact of social stigma experienced by the offenders leads to further interpersonal communication anxieties. This study aims to learn how the millennial generation addresses the social stigma faced by the offenders of Sharia law and how the offenders should act to be accepted by the society. This study uses a descriptive qualitative method in which the data were collected through in-depth interviews with seven informants. Informants were selected through purposive sampling technique and only the millennial generation who have exposed to canning news coverage were preferred. The results of the study indicate that the offenders were labeled negatively as sinners and isolated. The informants rejected such social stigma as it may hamper their rehabilitation.
\end{abstract}

Keywords_- social stigma; Sharia law; canning; Aceh

\section{INTRODUCTION}

Social stigma toward the offenders of Sharia law in Aceh is an interesting issue to discuss. They do not undergo the criminal penalty but canning punishment in the public space, which leads to the social pressures. This is undeniably a frightening scenario for those who committed the offense. Community involvement in such crime, particularly women, is considered inappropriate in Aceh that implements Sharia law [1]. Unpleasant stigma toward the offenders often escalate the public discrimination and triggers human rights abuses against the offenders [2].

The Secretary of the Public Order Agency and Sharia Police of Banda Aceh, Yusnardi, said that a total of 89 violators of the Sharia law who were found guilty by the Sharia Court were canned in 2016. With the figure of 60 people of the total offenders, gambling was the highest Sharia crime canned followed by adultery and drunk cases with the figure of 22 and seven offenders respectively. These offenders were charged with the Qanun Aceh Number 2, 2016 about Qanun Jinayat or Islamic crime. [3]
The canning becomes an unforgettable mental experience for the offenders. Their presence in the midst of the society becomes the subject of public discussion and social sanctions are gradually inflicted on the violators [4]. An important factor in analyzing violence is the level of social sanction support ones receives. For example, the extent of support adulterers get in comparison to the act of violence by the community will determine their survival [5]. However, social sanctions toward the offenders of Sharia law are so inherent in Aceh since the punishment is publicly performed in an open space. As a result, the distress and embarrassment implanted in the minds of the offenders are unforgettable.

Social stigma gives a psychological impact on the people who violate the social norms. In Tembalang Sub-district, for example, people with HIV are negatively stigmatized by the community. They are almost expelled from the community because the disease they suffer is regarded as dirty and disgusting [2].

The stigma the Acehnese people imposed on the offenders of Sharia law causes the perpetrators to be isolated and discriminated. As a result, their social interaction becomes limited and such condition often leads to stress and loneliness. Loneliness is a personal experience and ones will cope with it differently. Some people can bear the loneliness while others plunge to profound sadness. [6]

Lack of positive social interaction can lead to emptiness and depression. Individuals engaged in a positive relationship tend to be less affected in their day-to-day problems, have a high sense of control and are more independent. Conversely, without such links, they will become isolated, neglected and depressed. Due to the lack of contact with other people, ones may engender and maintain negative perceptions of self and assume less satisfaction and motivation in life [6]. Social interaction is the key to all social life; the absence of which may eliminate collective behaviors [6].

Burgoon and Ruffner in his book "Human Communication" explain that communication apprehension is an appropriate term to describe a negative reaction in the form of anxiety experienced by a person in his or her 
communication experience, either in public speaking or interpersonal communication [7]. This also applies to the offenders of Sharia law who, upon returning to their community, will experience obstacles in interpersonal communication within the society. People who suffer communication apprehension will find it difficult and feel anxious when having to communicate with others. They are often unable to reflect the sense of warmth, openness, and support [7]. Based on the above background, the authors intend to conduct further research on the social stigma imposed on the violators of Sharia law when engaging in interpersonal communication with their society.

The problem of interpersonal communication anxiety in Indonesia has been investigated by Mariani (1991). She found that $8 \%$ of 189 respondents, consisting of students from the Faculty of Psychology and Law, Muhammadiyah University of Surakarta, experienced interpersonal communication anxiety [7].

The millennial generation is the product of advanced technological development in another sense that has a distinctive mindset in addressing various social phenomena. The generation born in 1983 is a group of people who by 2000 was under 17 years old [8]. These are late adolescence whose final phase of identity formation took place before the age of 18 years old in which people are expected to have a commitment to the community social life in Indonesia. This group is referred to in various terminologies. Strauss-Howe called it the millennial generation, Don Tapscott designated it "Net Generation" while Graham Brown's named it "Mobile Generation" in his research. Since the term "millennial generation" is the most common term and is also more relevant to the current research context, the authors use the millennial generation term, to describe the generation born in the information age where media technology evolve and permeates everyday life.

In a study conducted by Heru Dwi Wahana entitled The Influence of Cultural Values of Millennial and School on Individual Resilience (Study in SMA 39, Cijantung, Jakarta), he found that millennial generation valued the technology as a lifestyle and considered themselves a sheltered generation as they are born from educated parents. They are multi-talented, multi-language, more expressive and explorative. Their views on the essence of life are confident, optimistic, confident, simple, and instant. In term of work, they perceive achievement as something that must be achieved. They work and learn interactively through teamwork, work collaboratively in a group, independently and orderly. They love to use technology, communication gadgets, and the internet and prefer visual cues or images [9]. With such critical views on the social phenomena, the authors aim to learn how the millennial generation address the social pressure experienced by offenders of sharia law in aceh.

\section{METHOD}

This study used the qualitative descriptive method. It is a research method that systematically, factually and accurately describe events about the facts, properties and relationships between the phenomena studied [10]. Descriptive research design can also be interpreted as a problem-solving procedure that is investigated by describing the state of the subject or research object (individual, community, and community institution) at the present moment based on salient facts or as it is [11]. The author conducted an in-depth interview with several millennial generations who actively attend the caning punishment imposed in Aceh.

According to Parsons to maintain its survival a social system must have requirements. First, the social system must get the necessary support from other systems. The offenders of Sharia law in Aceh receive very minimal support for their freedom to go back to their society. Second, the social system must be structured in such a way that it can operate in a harmonious relationship with other systems. Third, the social system must be able to meet the needs of its actors in a significant proportion. The offenders of Sharia law are in dire need of returning to normal life to their the community. Fourth, the system must be able to generate adequate participation from its members. Fifth, the social system must be able to regulate potentially disruptive behavior. Sixth, the system must be able to control the conflict that may cause chaos. Seventh, for its survival, the social system requires a language [12].

[13] propose the characteristics of interpersonal communication anxiety as follows;

- Unwillingness. Individuals have no interest to excel in communication due to anxiety and introverted nature.

- Avoiding. Individuals tend to avoid engaging in communication. This can be provoked by anxiety or lack of information about the communication situation they are facing.

- $\quad$ Skill acquisition. This theory states that individuals will feel anxious when they sense unsuccessfulness or are unsuccessful in developing his skills in communication.

- Modeling. This theory explains that communication anxiety evolves from the imitation process observed by a person in his or her social interactions. [7].

The cause of interpersonal communication difficulties is the presence of anxiety such as fear of receiving unpleasant responses or negative judgments from the persons receiving the messages [14]. The main problem in interpersonal communication anxiety is the feeling of worries about the response or judgment of others about what they are saying and how they delivered it [14].

Goffman (as cited in Hardiman) calls a person with a stigma as not entirely human. [15] argues, if we do it deliberately, we make a lot of discrimination to effectively reduce others' chances to live well. We have constructed a theory of stigma and ideology, which describes the inferiority and the danger of the stigmatized person.

Those who are stigmatized are not perceived as individuals, but as an element of a discredited group. They are excluded from "us" and tossed into "them" [15] Stigma implies disgrace, shame, inferiority, shyness and fearsome 
[16]. In this modern era, the term "stigmatization" is more conceived as "class" rather than "physical condition"[17]. Stigma signifies a "label" designated by the public upon a person. Stigmatized people behave as if they are in fact embarrassing or their reputation are defamed [18]. Stigmatization can alter people's perceptions and behavior toward the stigmatized individuals and usually induce the stigmatized persons to change their self-perception by defining themselves as deviances.

The experts classified the term "millennial generation," also known as generation $\mathrm{Y}$, based on its beginning and ending years. The millennial generation or generation $\mathrm{Y}$ is referred to those born in 1980-1990 and beyond [19]. It is also known as Generation Me, Echo, or Boomers. There is no clear-cut demography in determining this generation group. Borrowing the term Generation Theory by Natali Yustisia, there are five generations born after the Second World War and are related to the present time. They are: Baby Boomer (born 1946 - 1964), Generation X (born 1965-1980), Generation Y (born 1981-1994), Generation Z (born 19952010), and Alpha Generation (born in 2011-2025). In this study, the author only discusses Generation Y, known as the millennial or millennium generation. US newspaper editorial started to use the term generation Y in August 1993. This generation uses many instant communication technologies such as email, SMS, instant messaging and social media such as facebook and twitter. They also love playing online games.[19].

According to the American Psychological Association (APA), millennial generations experience more pressure and less able to manage it than other generations. More than half of them report to wake up at night due to stress. It is not surprising that the millennial generation is also more anxious than older Americans. APA says that $12 \%$ of millennials are diagnosed to have anxiety disorders at almost twice the percentage of Baby Boomer generation, born in 1946-1964 [20].

The formulation of the Aceh Qanun is based on the Qur'an and the hadith of the Prophet; by adhering to the interpretation of the Qur'an and the hadith, using the relevant old provisions and opinions of the scholars to formulate better new provisions, taking into account the local needs of the Acehnese people, and respecting human rights issues, the Convention against Torture and other cruel and inhuman punishment [21].

The implementation of punishment post-Islamic Monarchy of Nusantara was first performed in Indonesia, on June 24, 2005, in the courtyard of the Great Mosque of Bireun, Aceh. From 2005 to 2008, the total number of offenders undergone caning were 275 people. In the following years the number was decreasing, 101 people in 2005, 61 people in 2006, and 58 people in 2007 and 55 people in 2008 [21].

\section{FINDING AND DISCUSSION}

\section{A. Social Stigma toward the Offenders of the Sharia Law}

The results of interviews on how social stigma given by the community to the former offenders of sharia law show that some people always give negative views and perceived their acts as disgusting as reported by Andra Alfarisz 19 Years old, a Religious Activist and student in Aceh:

Looking at the stigma that emerges in the Acehnese community against the offenders of the sharia law, I conclude that they view the offenders negatively. These people have violated the sharia law, and the perpetrator had been punished according to sharia law and customary law. The intensity of objection is no longer as high as that at the beginning of their punishment. (Andra Alvarisz 19 Tahun 18 Juni 2018)

From the results of the above interviews, it can be concluded that social stigma will last a long time and take years to evade. If the offenders decide to return to the society and choose to return to the right path the stigma will fade and change into a favorable view. Every human being has a past and is entitled to have a second chance. Although some people will not forget about the incident, things will get better.

This indicates that some people strongly agree with the enactment of caning in Aceh because it will give the deterrent effect to the perpetrators. Furthermore, with the development of media technology, exposures of negative stigma not only comes from the local community but the exposure world can give a negative stigma to the offenders. However, it is unfortunate the media has become entertainment for some people to exhibit negative attitudes towards them rather than a warning for the community.

Another view is given by Chayumi, a 19 years old university student in Aceh. She argues that social stigma is not much different from offenders of criminal law that often lead to negative stigma.

The social stigma labeled to the violators of sharia law is not different from the offenders of state law who are subject to state sanctions (prison inmates). The stigma given to the violators of sharia law is most likely a negative one. In fact, I think it could be more negative than the offenders of the state law. The negative stigma that people deliver to sharia violators can be in the form of scorn, negative comment, insult, swearing, isolation and other perceptions and prejudices. (Chayumi, 19 Tahun 19 Juni 2018)

From the above statement, it can be noticed that caning punishment done publicly helps the community to be more familiar with and easily label the offenders. Negative stigmas are often given in the form of scorn, spicy comments, insults, swearing, and isolation. This results in the pressures and communication anxieties faced by the defenders.

\section{B. Self-Evaluation toward the Negative Social Stigma against the Offenders of the Sharia Law}

While some informants adhere to the society that gives a social stigma to former offenders of sharia law others do not. 
Some millennial generations do not agree with the views of the people who exclude the offenders. The punishment is sufficient and has given them a deterrent effect. Additional social stigma can only hamper their survival.

Other data were also found from the interviews conducted with Andra Yates:

I agree if the negative stigma is attached to the action, not to the perpetrator. Fundamentally, human beings cannot be separated from wrongdoing whether they do it intentionally or vice versa. Therefore, negative stigma should not solely be attached to the perpetrators but also to people who fail to unite and prevent them.

Some millennial generation accepts the social stigma if it is given to actions, not to the perpetrators. They believe that no humans can free of mistakes. Millennial generation also revealed that the violation took place due to lack of attention by the community about the importance of sharia law enforcement in Aceh.

Other data were also found from the interviews conducted with Chayumi:

I do not agree. After all, the offenders still have the life he has to build after being punished. They might want to build interpersonal relationships with others, try to find friends, or perhaps want to have a family, and raise children. Although what they did was unacceptable, they are still entitled to gain good treatment and positive prejudice from others. According to Maslow's need theory, humans need to feel appreciated and cherished by others around them, regardless of any sins they have committed. By giving a positive stigma, it can make them feel more welcome in the community and will likely be able to continue their life again.

Some millennial generations do not agree with the negative social stigma committed by society against the offenders. They worry if the perpetrator continues to get negative stigma, they may repeat their action or even worse.

\section{Recommendations to the Offenders of the Sharia Law}

The perspective of millennia generation on what the offenders should do when returning to society can be observed. Some millennial generations think that serious remorse is the first step the offenders need to do if they want to return to the community. The most important thing is to do good deeds to make people more confident that the perpetrator has returned the right path.

Some millennial generations argued that the offenders must fight harder to do good deeds. The offenders may need to move outside their society for some time until the society forget or forgive them and come back with better personalities than ever.

Other data were also found from the interviews conducted with Chadevi Jauhari.

They need to change, socialize and prove themselves. Prove that the perpetrator really wants to change their life. The public should support the changes that the perpetrators plan to do.
Some millennials argue that the perpetrators must really change, socialize and prove themselves as better persons. The community must also accept this positive change.

Some millennials recommend that the perpetrators need to be productive, adhere to themselves and improve their personalities. The offender must at least have one or few friends who can be trusted as a place to share their feelings so as not to feel lonely.

\section{Discussion}

The imposition of caning law to convicted offenders of sharia law in Aceh has contributed to negative stigma to the offenders in their social life. Caning publicly makes the community to be more familiar with the perpetrators. The negative stigmas often given by the community are in the forms of scorn, insult, curse and isolation. As the results, the perpetrators may experience pressure and anxiety in communication. There is social pressure for the perpetrators in conducting interpersonal communication with the surrounding communities. They often experience difficulties in conducting interpersonal communication with their surrounding society. According to some Acehnese people, the violation of Islamic law is a big sin. Thus, the community will be less empathy towards the violators of the law. This less empathy factor can also contribute to the interpersonal communication difficulties between the violators of the sharia law and the surrounding community.

As stated by [7], this empathy is an important factor in the process of interpersonal communication. In interpersonal communication, one must understand their interlocutors. Communicator or communicant must see that their interlocutors also have feelings. It is undeniable that what is done in the communication process will also affect the process of message acquisition. According to [7] and [22] through empathy, communicators or communicants will feel what others feel by reflecting themselves in the other person's position. Thus, the interpersonal communication will work effectively.

For the Acehnese people, the violations of Shariah law such as committing adultery is a very bad act. Negative stigma given to the offenders is based on the emotional attitudes of the society. Most of the Acehnese people support the execution of caning. The public argues that Sharia law should be applied thoroughly to regulate the life order of the society, including punishment against the offenders. Those who support generally come from Islamic education backgrounds such as Islamic boarding school and Islamic organizations. Those whose background other than that do not give a stronger stigma. However, they still accept the application of caning punishment for those who violate the sharia law. However, a small portion of the community refuses the execution of caning because it allegedly violates the Human Right. The enactment of the canning to the violators of sharia law can be regarded as a living social system in Aceh. According to [2], To maintain its survival, a social system must have requirements and should get support from the community. Only then will the social system run bindingly within the society. In the context of caning punishment, some 
people strongly agree, some partly agree and some do not. These diverse views are often driven by the knowledge background ones possess. According to [17], the freedom of the public in obtaining information in the present day will also affect their assessment of something including the assessment caning punishment to the violators of sharia law in Aceh. Negative stigma given by the community will give deterrent effect on the perpetrators. The disgraces gained from the canning punishment done publicly can be a lesson for the perpetrators and the community. This deterrent effect will cause anxiety to the members of the community who want to commit the same offense. In other words, caning punishment is a test of ones' faith in the form of face-saving. Perpetrators are advised to repent in an effort to improve their relationship with God and regularly pray in the mosque. Thus, the society will look at the offenders as a convert and will lower their level of negative stigma toward them.

\section{CONCLUSION}

Some people address the issue of sharia law violations by giving negative views and regarded it as disgusting acts. The negative social stigma attached to them will last for a long time and takes many years to recover over time until the former convicts decide to return to their society and decide to do the right deeds. Some people strongly agree on the imposition of caning punishment in Aceh as it will give the deterrent effect to the offenders. With the development of media technology, negative stigma no only comes from the local community but also the whole world. The imposition of the canning punishment in the public space only helps induce the community to be more familiar with the faces of the perpetrators. There is a disagreement toward the view of society that isolates the offenders. Some believe that the canning and shameful effects should be adequate as the sanctions. They rejected the social stigma given to the former convicts as it may hamper their survival. Some millennial generation agrees if social stigma is given to the actions, not to the perpetrators. They believe that everyone makes mistakes. Others argue that such violations occur due to the lack of care of the community on the importance of sharia law enforcement in Aceh. They believe that should the negative social stigma toward the offenders continue to prevail, the situation may unexpectedly get worse.

\section{REFERENCES}

[1] W. Fitri, "Perempuan dan Perilaku Kriminalitas: Studi Kritis Peran Stigma Sosial Pada Kasus Residivis Perempuan [Womamn and Criminal Behavior: Critical Study of Social Stigma Role on the Cases of Woman as Recidivist],” Kafa’ah J., vol. 7, no. 1, pp. 6778, 2017.

[2] M. I. Katili, R. Indrai, and Y. Kartikasari, “Attitude and Action Mother With HIV Aids on Stigma and Discrimination People at Semarang City,” LINK, vol. 8, no. 1, pp. 1-24, 2012.

[3] Aktual.com, “Sepanjang 2016, 89 Pelanggar Syariat Islam di Aceh Kena Hukum Cambuk [On 2016, 89 Sharia Law Violators in Aceh have been Flogged],” Aktual.com, 2017. [Online]. Available: http://www.aktual.com/sepanjang-2016-89-pelanggar-syariat-islamaceh-kena-hukum-cambuk/.

[4] H. Hermawan and H. Andrianyta, "Peran tambahan modal terhadap pendapatan usaha ytani padi [Role of investment improvements towards rice farming income],” Pengkaianj. dan Pengembangan.
Teknologi. Pertan., vol. 16, no. 2, pp. 132-139, 2013.

[5] S. Fitrianingsih, "Faktor-faktor penyebab tindakan kekerasan terhadap perempuan dalam rumah tangga [Causal factors of abuses towards woman in the household]," vol. 11, no. April, pp. 127-146, 2016.

[6] D. Ayu, "Kesepian dan isolasi sosial yang dialami lanjut usia: Tinjauan dari perspektif sosiologis [Loneliness and social isolation on the elders: Reviews from sociological perspective],” Informasi, vol. 18, no. 03, pp. 3-4, 2013.

[7] L. H. Wulandari, "Efektivitas Modifikasi Perilaku-Kognitif Untuk Mengurangi Kecemasan Komunikasi Antar Pribadi [Effectivity of Cognitive Behavior Modification to Reduce Interpersonal Communication Anxiety],” e-USU Repos., pp. 1-15, 2004.

[8] N. Howe and W. Strauss, "Millennials Rising: the next generation," Vintage, 2000.

[9] H. D. Wahana, "Pengaruh Nilai-Nilai Budaya Generasi Milenial dan Budaya Sekolah Terhadap Ketahanan Individu (Studi Di SMA Negeri 39, Cijantung, Jakarta) [Influence of Millenial Generation's Cultural Values and School Values towards Individual Resilience],” Ketahanan Nas., no. April, pp. 14-22, 2015.

[10] L. Moleong, "Metodologi penelitian [Research Methodology]," Metodol. Penelit. Kualitatif, pp. 31-44, 2006.

[11] H. Nawawi, Metode Penelitian Bidang Sosial [Social Research Methods]. Jakarta: Gajah Mada University Press, 2001.

[12] S. Purnomo, "Krisis Karakter [The Crisis of Characters]," J. Pembang. Pendidik. Fondasi dan Apl., vol. 2, no. 1, pp. 72-81, 2014.

[13] M. Ruffner and M. Burgoon, "The Relationship Between Writing Style And Personality Structure.,” Newsp. Res. J., vol. 2, no. 2, pp. 28-35, 1981.

[14] S. \& E. H. P. Siska, "Kepercayaan Diri Dan Kecemasan Komunikasi Interpersonal Pada Mahasiswa [Confidence and Interpersonal Communication Anxiety on Students],” J. Psikol., vol. 2, no. 2, pp. 67-71, 2003.

[15] S. Yuliani, "Menguak Konstruksi Sosial di Balik Diskriminasi terhadap Waria [Revealing Social Construction Behind Shemale's Discrimination],” J. Sosiol. Dilema, vol. 18, no. 2, pp. 73-84, 2006.

[16] S. Peter, The Contemporary English - Indonesia Dictionary, 7th ed. Jakarta: Modern English, 1996.

[17] Soedarjatmi, T. Istiarti, and Laksmono Widagdo, "Faktor-faktor Yang Melatarbelakangi Persepsi Penderita Terhadap Stigma Penyakit Kusta [Background Factors of Patient's Perception towards Leprosy's Stigma],” Promosi Kesehat. Indones., vol. 4, no. 1, 2009.

[18] T. Dayaksini and Hudariah, Psikologi Sosial [Social Psychology], Rev. Ed. Malang: UMM- Press, 2003.

[19] T. Mutia, "Generasi Milenial, Instagram dan Dramaturgi : Suatu Fenomena dalam Pengelolaan Kesan di Tinjau dari Perspektif Komunikasi Islam [Millennials, Instagram, and Dramaturgi: A Phenomenon in Impression Management, Reviewed from Islamic Communication Perspective],” J. Pemikir. Islam, vol. 41, no. 2, pp. 240-251, 2017.

[20] Hermanto and S. Febriyani, “Kecemasan Terhadap Berita Hoax Ditinjau Dari Strategi Emosi Pada Millennial Mom [Worriness of Hoax News Reviewed from Emotional Strategy on Millennial Moms],” JPPP-Jurnal Penelit. dan Pengukuran Psikol., vol. 4, no. 1, pp. 12-17, 2015.

[21] Ma. Ablisar, "Relevansi Hukuman Cambuk Sebagai Salah Satu Bentuk Pemidanaan Dalam Pembaharuan Hukum Pidana [Relevance of Flogging as one of Punishment in the Reform of Penal Code],” J. Din. Hukum, Purwokerto Fak. Huk. Univ. Jenderal Soedriman, vol. 14, no. 2, pp. 278-289, 2014.

[22] J. Ulfah, Miani, "Memahami Prilaku Empati Komunikasi Antar Pribadi dalam Persahabatan di Jejaring Sosial Path [Understanding Interpersonal Communication Empathy Behavior in Friendship in Path Social Network],” Diponegoro Univ., 2015. 